U. S. Department of the Interior

Geological Survey

Missouri River Bàs in

Geologic Mapping and ilneral Resource Investigations

Missouri-Souris Unit

Arieal Geology

Preliminary. Report on the

Geclogy of the Kermit No. 3 Quadrangle,

North Dakota

By

Robert M. Ifndvall and Wallace R. Fansen

1947

$4 / 8 \cdot 9$ 
CONTINTS

Mas

INTRODUCTICN . . . . . . . . . . . . . . . . . . .

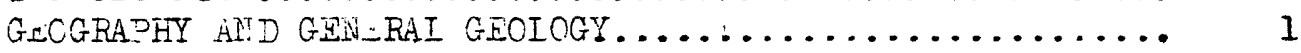

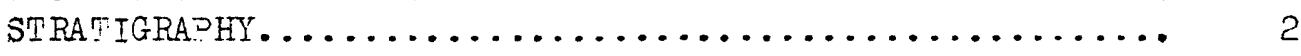

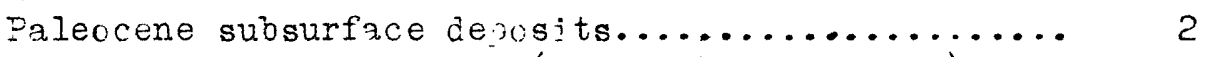

Fort Union formation (rongue River member)..... 2

- Pleistocene devosits....................... 2

Pre-late Wisconsin drift................ 2

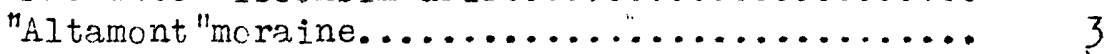

PrellAtamont"Wiscons in grcund moraine......... 4

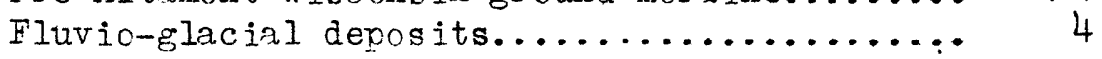

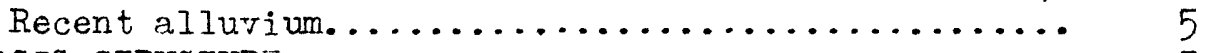

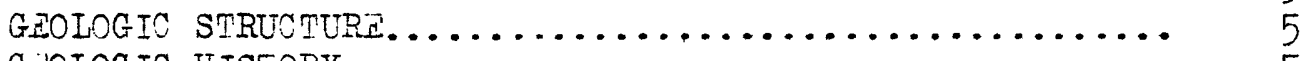

GEOIOGTC HISTORY........................ 5

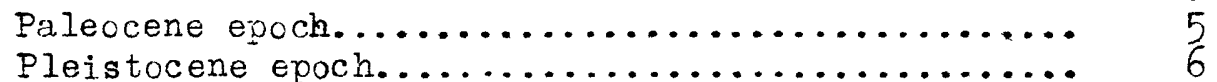

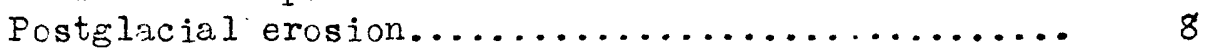

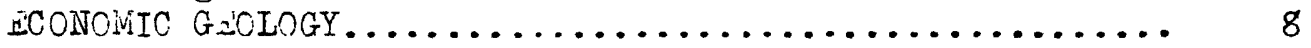

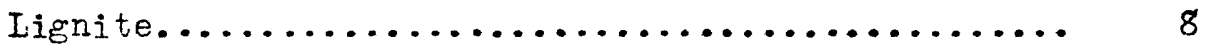

Construction materials.................... 8

Sand and gravel......................... 8

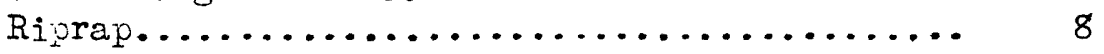

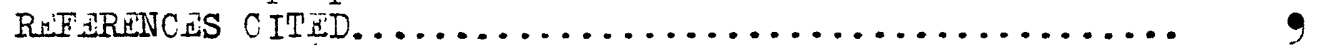


The present study of the areal geology of the Kermit No. 3, 15 minute quadrangle, completed during the summer of 1946, was made in connection with development of the Missouri-Souris Unit of the Missouri Basin Development Program. The quadrangle is located in northern Williams County and southern Divide County. It lies within the Missouri Plateau section of the Great Plains Province (4,・no. 4). Part of the proposed Crosby reservoir enters the area and the route of the proposed Souris canal of the U. S. Bureau of Reclamation crosses the quadrangle.

\section{GEOGRADHY AND GENERAL GEOLOGY}

The Kermit No. 3 quadrangle and surrounding area is covered by thick deposits of glacial drift deposited during the Wisconsin state of Pleistocene glaciation. The drift consicts mainly of morainal deposits of late Wisconsin age. The "Altamont" moraine (3, po. 388 and 393; 6, p. 521; 1, p. 126) occupies the northern three quarters of the area, and earlier ground moraine $(1,0.127)$ occupies the southern quarter.

The "Altamont" terminal moraine consists of thick till (up to 200 feet) having an irregular, poorly drained surfoce of high relief. The ground monaine has a relatively smooth surface with rather well integrated drainage patterns.

There are no bedrock exposures in the auadrangle, but mine shafts reach coal at 2 depth of 30 to 50 feet in the vicinity of cottonwood lake east of Alamo. Well borings indicate that the Tongue River member of the Fint Untion fcrmation of Daleocene age underlies the glacizl deposits at depths ranging from 30 to 200 feet.

Large gravel cutwash deposits are found in Alamo Valley, and in the northwest corner of the quadrangle. iskers comoosed of sands and gravels, and veneered in places with varying thicknesses of boulders and till, occur 4 and 8 miles north of Alamo, and east of Cottonwood Iake. Small gravel terraces are located along the banks of Little Muddv Creek and its tributaries in the southern purticn of the quadranfile. Isolated gravel knobs are scattered throughout the terminal moraine area.

The climate of the region is semi-arid, the mean annual precipitation being about 14 inches. Sumpers are generally mild and winters quite rigoruus. Secondary lime, occurring chiefly in the form of caliche, has been and is being widely deposited in the subscil and as encrustations on the undersides of surface stones. Similarly, along road-cuts and entrenched streams, exposed faces of till frequently are case-hardened by deposition of lime, induced by capillary action and evaporation. All of the streams of the area are intermittent and carry little water except after rains and thaws. The drainage, where integrated, is in general to the south and west to Iittle Muddy Creek. 
The original vegetation, where not remored by cultivation, is of the "long grass" prairie type, with patches of "buck brush" and occasional cottonwood trees scattered a zong the streams. Wheat and grain cereals are the chief agriculturel products and the grasslands are utilized extensively for livestock pasturage.

\section{STRATIGRADHY}

\section{Paleocene subsurface deposits}

Fort Union formation (Tongue River member). - Formations older than the Tongue River menber of the Iort Union formation (Paleocene) are not encountered in this area. No deep well borings are recorded within the quadrangle, so information from that source is lacking. Fowever, cne deep well, the California Comoany's Kamo No. 1, has been drilled to a deoth of 10,281 feet in illiams County twenty miles to the south. Whe following systems and thicknesses were recorded in this well: Tertiary - 800 feet, Cretaceous - 3,820 feet, Jurassic - 900 feet, Triassic - 970 feet, Carboniferous (Mississipoian) $=3,160$ feet, Devonian - 631 feet. (5, po. 13-14)

There are no surface exposures of the Tongue River member in this quadrangle. Howevor, information gathered from abandoned coal mines two miles east of Alamo indicates that lignite horizons in this member are present in the valley walls at a deoth of about thirty feet below the valley floor and at an elevation of aporoximately 2,075 feet. In addition to the coal, traces of clinker or "scoria" are present on the dump piles of the mines. Clinker is formed during burning of the lignite, ignited at or near the outcron by siontaneous combustion, lightning, prairie fires, or artificial means. Heat generated by the fires causes partial baking to comolete fusion of the overlying clavs, shales, or sandstones, and imparts in them a distinctive coloration in shades of red, orange, or brown through oxidation of the iron-bearing minerals oresent. Masses of till baked to clinker in nearby areas outside the ouadrangle prove oostglacial burning of at least some of the ccal.

The Tongue River member in this quadrangle is covered by Dleistocene glacial deposits ranging from 30 to over 200 feet in thickness.

\section{Pleistocene deposits}

Pre-late Wisconsin drift.-Previous studies by several workers indicate two or more advances of ice into this region prior to the late wisconsin glaciation. Alden's map ( 1 , pl. I) indicates a broad belt of pre- "Altamont" Wisconsin ground moraine stretching suuthward from the "Altamunt" moraine te an east-west trending boundary six to eight miles south $f$ the quadrangle, where there are areas of end-moraine topography. He further mapoed as "Illinoian or Iowan", a sheet of drift extending suuthward from this line to a limit thirty-five to forty miles scuthwest of the Missouri River, where only scattertd boulders and occasinnal patches of till give evidence of glaciation. 
Earlier, Ieonard (6, p. 532) ccnsidered ore-"Altamont" Wisconsin drift to stretch from the southern boundary of the "Altamont" moraine to the present course of the Missouri River.

No contacts between any of the above-mentioned drifts have been seen in this area, and the boundary here mapoed is therefore tentative and approximate. The distinction is made largely on topograohic evidence. Furthermore, textural differences in the topograohy north and south of Alamo valley, due to differences in size, number, and distribution of closed depressions, suggest the oossibility of more than one period of deposition in the "Altamont" moraine itself.

Direct evidence of any pre-Illinoian or pre-Iowan glacial advance into the region is lacking. Whether Nebraskan and Kansas drift is present and is buried beneath younger deposits, whether the drift has been largely incorporated into younger deposits, or whether it ever was deposited is not yet known.

"Altamont" moraine.- The "Altamont" moraine represents the scuthwestern terminus of the Dakota lube of the late Wisconsin (Mankator) glaciation. It extends southeasterly in a belt fifteen to twenty miles wide from Canada across North Dakota from the northwest corner to the southcentral part of the state, whence it turns southward toward and beyond Altamont, South Dakota, the type locality. However, the use of the term "Altamont" for the terminal moraine is disputed by Leverett (7, v. 67) who points cut that at the type locality another moraine, the Bemis, lies outside it. Whether the moraine here identified as "Altamont" is actually the correlative of the Altamont, South Dakota moraine is therefore open to question, but for convenience of nomenclature, usage of the term is continued here.

The moraine consists chiefly of poorly compacted, calcareous blue-gray till, oxidized to grayish-brown, and containing numerous 1 ocal dejosits and lenses of sand and gravel, and extensively scattered cobble and boulder tracts. Mcst of the coarse material is foreign to the region, but much of the finer fraction has been derived from the underlying Tongue River sediments. Gray and red granites, pegmatities, and gneisses are the most abundant rock tyoes, but light-gray and pink fossiliferous, dolomitic limestones, "Flaxville" type quartzites, lignite, and basic igneous and metamorphic rocks are present. Boulders ranging uo to four or five feet in diameter are common, and all gradations from rude angular fragents to well faceted, polished, and striated stones occur.

The topuzraphy of the terminal moraine is of the knob and kettle tyoe, very youthful, with hummocky, ungraded profiles, many large undrained depressions, marshes, alkali lakes, gravel knobs, and till hills. Overall relief exceeds 300 feet and closure on individual kettles and closed depressions is often fifty feet or more. Drainage patterns are poorly developed, with no permanent streams. 
Pre- "Altamont" Wisconsin ground moraine.- The pre- "Altamont" ground moraine of Alden ( 1 , DI. I) covers the southern quarter of the auadrangle and is reflected topographica ly by a rather well developed drainage pattern and subdued relief. The topography is of the shallow basin or saucer twoe, in contrast with the terminal moraine. Nany of the numerous flat depressions have been connected by minor intermittent stream channels, and a rather complete, fairly well integrated drainage pattern has been formed.

Fluvio-glacial deposits.- Meltwaters discharging from the late Wisconsin ice front deosited outwash graveis and sands as extensive valley trains in Alamo Valley and in the northwest corner of the quadrangle in the topographic low believed to ve the buried channel of the preglacial Yeliowstone River (1, P1. I). Nearness of the ice front during deposition of the outwash material is indicated by the pitted nature of the outwash surface. Ice blocks, large and small, must have been partially to completely buried under loads of debris. Cottonwocd Iake east of Alamo appears to have had just such an origin, for it is complete? enclosed by fluvio-glacial gravels.

Projecting into the east end of Cottonwood Iake, and trending easterly through the vallev, and northeasterly toward and bevond Corinth, lies an esker having an overall length exceeding eight miles. It is braided and sinuous throughout most of its course and in places is discontinuous, disacoearing under an cutwash apron which partially surrounds it, and reap earing further on. Apparently subglacial streams utilized Alamo Valley prior to the disapvearance of the ice there. As stagnation and retreat of the front proceeded, a large ice block was left behind to protect the site of Cottonwood Iake from comolete aggradation, but the esker was left exoosed and detritus laden waters discharging from the glacier buried its lower segments. Again, it is completely mantled in places with a veneer of till, retaining however, its original topographic expression. This till is prcbably englacial drift let down during ablation. Small gravel pits for local use have been ovened in many places along the length of this esker.

Four miles north of Alamo in the westcentral portion of the quadrangle is $a n$ elongated fluvio-glacial tract of knobby, gravel hills, trending northeast-southwest for abcut $21 / 2$ miles. In oart it is of eskerlike form, but much of it consists of clu'sters of rounded, firirly symmetrical knobs. Heavy boulder concentrations cover most of the gravel surface, and in other places it is mantled with varying thicknesses of till. Gravel pits have been opened near the western end.

Similar to the above, but smaller, is a tract near the northenst corner of tine quadrangle in sections 1 and 2, T. $160 \mathrm{~N} ., \mathrm{R} .98 \mathrm{~W}$. 
Recent alluvial deposits, projably in oart fluvio-glacial outwash, occur in a narrow belt along the channel of Iittle Muddy Creek in the southern part of the quadrangle. The flocdplain consists of dark gray clays and silts uo to five or six feet in thickness. Mixed with the clavs and silts are sands and fine gravels, crudely bedied and with a fair degree of sorting. Below this thickness a coarse sand layer extends to an unknown depth, and is responsible for the oools of fresh water which remain in the channel through underground flowage during the entire sumner.

Alluvium also covers the bottom of most of the larger lakes and undrained depressions, consisting for the most part of reworked glacial clay, silt, and fine sand. The valley trending five miles eastward from Alamo and south of cottonwood Iake is floored to an unknown deoth with colluvium, mainly reworked till from the adjacent valley walls.

\section{GEOLOGIO STRUCTURI}

Vell borings into the Dakota sandstone indicate that western North Dakota is structurally a large, gently sloping trough to which the name Daketa (or Villiston) Basin has been given (2, c. 1568). The Yermit No. 3 quadrangle lies on the northern flank of the basin. The rongue River menber of the Fort Union formation underlving the glacial deposits in this area has been only slightly, if at all, disturbed since deposition, the beds being essentially horizontal with a slight southeastward dio to the Dakota Basin. Inasmuch as there are no outcroos in the quadrangle, the structure can be interpreted only through well logs. The limited amount of this data indicates dios of less than one degret. No evidence of faulting has been observed in the quadrangle.

\section{GAOIOGIC HISTORY}

\section{Drleocene exoch}

Warm, continental conditions oersicted throughout Fort Union time, and extensive forests probably covered much of North Dakota. The mongue River member of the Eort Union contains numercua rema ns of terrestrial and fresh water plants and animals. Previous workers $(6, j .3)$ have identified a large zssemblige of conifers and deciduous trees, including senuoin, cyoress, juniper, porlar, fig, dogwood, hickorv, oak, and ginko, all occurring chiefly in the lignite. In addition, various turtles and alligators as well as invertebrates have been described.

Swamy, humid conditions must have occurred repeatedly and persistently for long periods of time, $a 6$ indicated by the presence of several thicknesses of lignite in nearby areas outside the quadrangle. 
Besides the coal, the rongue River member consists predominantly of well stratified clay and shale. Stable, quiet concitions must have attended their deposition, though the presence of ccarser sand and silt, often strongly cross-bedded, indicates transporting currents of considerable velocity. For the most part, conditions of deocsition must have fluctuated, causing inte fingerings of coarser material to successively fill and bury the coal swamps and shallow lakes.

\section{Pleistocene epoch}

During the long Deriod of erosion between the deocsition of the Paleocene sediments and the invasion of the Pleistocene glacicrs, normal dissection of the area had been in progress, and northeastward flowing streams and their tributaries orc bably had produced a tooosraphy in the rermit No. 3 quadrangle similar to that now found in the bacland areas along the Iittle Missouri Fiver in southwestern North Dakotz.

The preglacial Yellowstone River $\left(1,0.5^{\alpha}\right)$ is believed to have followed a course uo the val ley of the present Ijttle whdy Creek, flowing northward across the adjoining Zahl No. 4 auadrangle to the west, and cutting the northwest corner of the Kermit No. 3 auadrangle before flowing into Canada northwest of Crosy, N. Dak.

With the advance of the first ice sheet, the northward courses of the preglacial Yellowstone and Missouri were blocked. No evidence of oonding has been found in the arta, and presumably the streams assumed southward courses aporoximating their present-day channels. In addition, the preglacial topography was greatly modified as the overriding ice abraded the hills and filled the valleys with debris.

Sevtral "ghost" channels, presumably filled valleys, cross the southern half of the quadrangle. Alamo Vallev is surh a channel. Information regarding depth to bedrock in these is laciring, but well borings at Alamo indicate outwash sands and erarels to a depth of at least 60 feet. These valleys are $b \in l i e v e d$ to represent ice marginal channels carved by diverted drainage, possiblv the confluent Missouri-Yellowstone flowing eastward as it was pushed progressively southward by the advancing ice. Alden (1, r.58) believes the preglacial Yellowstone to have flowed up the course of the resent Iittle Muddy Creek just beyond the southwest corner of the quadrangle. The possibility cannot be ignored that some of the channels, at least, rerresent valieys of preglacial streams. Hcwever, the striking parallelism which they exhibit, and the general northwestward slope of the country do not seem comotible with this notion. It also is possible that escape waters from the ice sheet, if not ovorloaded, could have zccomolished the cutting. At any rate, the channels must have been carved in advance of the last ice because except for Alamo Valley, most are undrained at both ends, contain kettles, and are floored with till. Closure, in many cases exceeding 50 feet, and absence of sorted sediments in the floors of most refute the possibility that they might have been carved by meltwaters from a retreating or stagnating ice front. 
The present width of the valleys, zveraging 400 to 500 feet, may not seem adequate to accommodate a stream the size of the Miscouri-Yellowstcne. However, the buried channels are probably considerably wider. This is evidenced in many places by widening where they are floored with kettles. Ice blocks at these places must have prevented some of the constriction and filling due to burial that occurred elsewhere. The oresent result is $a$ beaded apearance. It also must be remembered that filling orobably was contributed by more than one period of glaciation.

Similar channels are present bevond the southern boundary of the quadrangle and in the adjoining Zahl No. 4 auadrangle to the west. In the Zahl No. 4, Scoria Valley, also believed to be such a channel, has widths commonly as much as half a mile. Here the Ficrt Union formation outcrons in the valiey walls. Alamo Valley in olaces has comorable width without bedrock exposures.

The Great Northern Railroad has utilized Alamo Valley and adjoining channels to the eastward in routing its Grenorz branch line through the rough terrain of the moraine.

The "Illinoian" or "Iowan" glacier ( 1, r. 88) advanced far beyond the limits of the quadrangle, further diverting the drainage, and devositing drift in the Missouri channel near Williston. The ice did not remain long trough for de $\in$ p re-entrenchment of the drainage to occur however, for the Missouri re-occupied its present channel when the glacier withdrew.

An. early Wiscons in ice shett advanced acproximately six to tight miles beyon the scuthern boundary of the quadrangle, and remained long enough to deoosit a fairly large end moraine. Frosion has since redur ed this to isolated patches of morainal topography.

The final advance of the ice into this region prcduced the great "Altamont" moraine which covers must of the audarangle. All of the major outwash deposits, most of the gravel knobs, and the eskers are oroducts of this substage. The pitted nature of the outwash plains, including the channel of the preglacial Yellowstone, and the presence of the eskers suggest that the ice finally disappeared from the area through stagnation due to thinning for lack of nourishment rather tran through orderly retreat of an active ice front. Presence of a thin till veneer in places comoletely mantling the eskers, howev $r$, leaves open the auestion as to whether fluctuating readvances occurred, or whether englacial drift merely was let down as a blanket during zblation and final disapoearance of the ice.

In the northwest part of the auadrangle $a$ lobe or block of ice is believed to have stood temocrarily in the channel of the oreglacial Yellowstane, and marginal s'reams fluwing between the valley sides and the ice itself are thought to have deoosited the kame-terrace gravel deposits located there. 


\section{Postglacial erosion}

Since the retreat of the last glacier, normal erosional processes have been in progress, but such a short time geologically has elansed, that only slight and minor modification of the glacial topography has occurred. A few intermittent streams now drain the older southern portion of the area, although dissection there ia by no means complete. The remainder of the quadrangle is escentially as the ice sheet left it. The banks of some of the larger kettle ponds have been modified to some degree by wave action, as at Cottonwood Iake, but aside from this, minor sheet flood erosion, rill action, and wind erosion, especially in areas now under cultivation, are the only urocesses operative.

\section{ICONOMIC GEOLOGY}

\section{Iignite}

Small lignite mines have been operated in the vicinity of Alamo and Corinth, but little information is available as to the nature of the coal beds. Near cottonwood lake the coal is reported to lie in the valley wall twenty-five to thirty feet below the surizce. Test borings might prove this area to be feasible for sinall scale strip mining.

\section{Construction materials}

Sand and gravel.- The best sources of sand and gravel in the area are in the laręe cutwash channels in the vicinity of Alamo and in the northwest part of the quadrangle. Esker deosits and gravel knobs provide material for manv local requirements. Isolated patches of alluvial gravel cccur along Iittle Maddy Creek and some of its tributaries. Most of these areas have been exploited to some extent far road material and local construction work. The deoosits generzlly are not well sorted and usually contain considerzble amcunts of sand. Iignite slack is sometimes present, and calichification is common. As taken from the oits, the materizl usuliy is suitable for secondary road material, and with oreliminary screening and washing may be used for general construction work.

Materials probably deleterious to use for concrete aggregate with high alkali cements are present to some degree in most deposits. These include chert, chalcedony, and rhyolite anc related rocks. As percentages vary widely in different deoosits, individual samoles should be studied before higin alkali cements are used.

Riprap.- Boulder piles, heaped uo by farmers in clearing their fields for cultivation, are present in nearly all sections of the quadrangle. At

- best the supply is limited, and size, shape, and rcmoosition of the stones inay further limit their use to small scale construction work. In this regard, schistose rocks, which are quite common, are particularly unguitable and some hand sorting therefore would be necessary.

Other boulder concentrations oc-urring naturally in morainal ridges and knobs could be gathered for riprap. 
1. Alden, i. C., Physiograchy and glacial geology of eastern Montana and adjacent areas: U. S. Geol. Survey Prof. Paper 174, 1932.

2. Ballard, Norval, Regional geclogy of the Dakota Basin: Am. Assoc. of Pet. Geologists Bull., vol. 23, no. 10, 1942.

3. Chamberlzin, T. C., Preliminary jater on the terminal mcraine of the second glacial exoch: U. S. Geol. Survey $3 d$ Annual heport, 1883.

4. Fenneman, N. M., Physiograohic divisions of the United States: Association American Geographers Annals, vol. 15, no. 4, 1928.

5. Laird, W. M., Subsurface stratigra ohy of the Nescon Anticline; N. D. Geol. Survey Bull., 21, 1946.

6. Leonard, A. G., The Pre-Wisconsin drift of North Dakota: Jour. Geol., vol. 24, 1916.

The lignite depcsits of North Dakota: N.D. Geol. Survev Bull. 4, 1925.

7. Leverett, Frank, Quzternary geology of Minmesctz and parts of adjacent states: T. S. Geol. Survev Prof. Jaser 161, 1932. 